Ethiopian Journal of Environmental Studies \& Management 7(3): 279 - 288, 2014.

ISSN:1998-0507

doi: http://dx.doi.org/10.4314/ejesm.v7i3.7

Submitted: January 9, 2014

Accepted: April 9, 2014

\title{
IMPACT OF NATURAL WEED INFESTATION ON THE PERFORMANCE OF SELECTED SUGARCANE VARIETIES IN THE SOUTHERN GUINEA SAVANNA OF NIGERIA
}

\author{
${ }^{*}$ TAKIM, F. O., FADAYOMI, O., ALABI, M.A. AND OLAWUYI, 0. J. \\ Department of Agronomy/Sugar Research Institute, University of Ilorin, P.M.B. 1515, Ilorin, \\ Nigeria.
}

\begin{abstract}
Experiments were conducted to evaluate the performance of some sugarcane varieties against natural weed infestation. The trials were laid out in a randomized complete block design with split-plot arrangement and three replications. The sugarcane varieties were the main plots while the sub-plots consisted of weeding regimes. Recommended cultural and agronomic practices were followed to raise the crops. Data were collected on weed density, weed biomass, sugarcane tiller count and cane yield. Our results revealed that Rottboellia cochinchinensis (Lour.) W.D.Clayton, Panicum maximum Jacq, Imperata cylindrica L., Panicum repens L., Cynodon dactylon L. and Cyperus rotundus L. were the major weed problems of sugarcane in llorin. The monthly hoe weeded treatment had significantly higher tiller count which translated to higher cane yield (22.61 to $72.54 \mathrm{t} / \mathrm{ha}$ ) than other weed control treatments. The reduction in cane yield was between 80.51 and 97.55\% depending on duration of weed infestation. Association of weed parameters with cane yield was negative and significant showed that a decrease in weed infestations will result in simultaneous increase in sugarcane yield. Therefore, in selecting sugarcane variety(s) for breeding programmes, emphasis should be placed on sugarcane growth parameters that negatively and significantly correlated with weed infestation.
\end{abstract}

Key Words: Weeds, sugarcane, plant crop, ratoon, cane yield, tiller count

\section{Introduction}

In Nigeria, sugarcane is widely grown on a small scale for home consumption and on a large industrial scale for the manufacture of refined sugar and it's by products. The small scale sugarcane production is characterized by low productivity of the sugarcane crop as yield losses of over $50 \%$ have been reported under the small scale cultivation (Ndarubu et al., 2006). This suboptimal production levels can be attributed to many factors including susceptibility of the local sugarcane varieties to pests and diseases, low level of adoption of improved technologies, marginal productivity of their farm land and high cost of inputs, especially nitrogenous fertilizers among others. The national average yield of sugarcane is less than $30 \mathrm{t} \mathrm{ha}^{-1}$ which is much lower than the world average, of $65 \mathrm{t} \mathrm{ha}^{-1}$ (Anon., 2008).

Sugarcane differs from other crops in that it takes twelve months to mature and at least three harvests (plant crop and two rations), and in some cases four to five harvests are made from a single planting. Consequently, the soil on the row top where the sugarcane grows is not appreciably disturbed during the multi-year crop which allows the weeds to become well established and difficult to control. The yield potential of sugarcane crop is affected by $20-25$ percent (\%) due to weed infestation (Khan et al., 2004). Weed management therefore in sugarcane accounts for over $35 \%$ of the cost of production.

Weeds constitute a major factor limiting sugarcane production in Nigeria. The competition for water, light, nutrients and space between weeds and the crop can reduce sugarcane stalk population and yield. Weed interference is a major biotic constraint to optimal crop production. Singh et al. (1980) reported that weed - crop competition is effective for 120 days of crop and zero weed-crop competition for first 120 days of growth period enhanced $45 \%$ cane yield. However, after 120 days, zero competition was not beneficial. The weed competition starting from 3, 6 and 9 weeks after planting reduces yield by $77.6,50.6$ and $41.7 \%$, respectively (Zimdahl, 1980). Punzelan and Cruzz (1981) concluded that weed-crop competition for first 
two months (60 days) after planting the crop reduced cane yield by $8 \%$ at harvest compared to weed free. Study conducted by Phogat et al. (1990) showed that weeds posed serious threat to sugarcane crop especially between 60-120 days after crop planting while results of study conducted by Nayyar et al. (1994), revealed that $86.7 \mathrm{t} \mathrm{ha}^{-1}$ cane yields was obtained from weed free duration up to 90 days, closely followed by weed free duration up to 56 days with an average yield of $80 \mathrm{t} \mathrm{ha}^{-1}$. Srivastava et al. (2003) opined that weeds infestation caused between 12-72 1\% reductions in cane yield. Singh and Tomar (2003) reported that when weeds were removed after competition for $30,45,60$, and 75 days, a reduction of $17.5,23.8,59.7$, and $74.7 \%$, respectively in cane yield was recorded while Patel et. al. (2007) revealed that cane yield increased to $98.1 \%$ with increasing weed free period and decreased to $38.1 \%$, when weed-crop competition for 3-4 months.

Plant breeding programme develop varieties primarily to increase yield and resistance to diseases/insects with little emphasis on weeds and herbicides tolerance. Hence, the importation sugarcane varieties also take advantage of the available high yielding sugarcane genotypes which may exhibit poor yielding ability in the new environment. One of the reasons for low yield may be poor competitive ability with the native weeds. The study reported herein was therefore undertaken to assess the effect of natural weed infestation on the growth and cane yield of sugarcane.

\section{Materials and Methods \\ Site Description}

This study was conducted at the University of Ilorin Sugar Research Institute's Farm between 2009 - 2011 growing seasons. The farm is located at Bolorunduro, Ilorin, in the southern Guinea savanna ecological zone (Latitude 90 29' $\mathrm{N}$ and Longitude $4035^{\prime} \mathrm{E}$ ) of Nigeria, and is $307 \mathrm{~m}$ above sea level.

The study was established in 2009 using a site that had been under continuous sugarcane cropping for more than a decade, the site used in 2010 (plant crop) and 2011 (ratoon crop) was under fallow for about a decade and had never been cropped to sugarcane while 2011 site was sugarcane growing field that was under fallow for about 5 years prior to the commencement of the study.

\section{Experimental Layout}

In each year, the experiment was laid out in a randomized complete block design (RCBD) with a split-plot arrangement and three replications. The main plots consisted of five sugarcane varieties (B47419, Co 61275, Co 957, ILS 001 and ILS 002) while the sub plots consisted of six weed infestation, made up of a weedy check, one hoe weeding at 4 weeks after planting (WAP), hoe weeding at $8 \mathrm{WAP}$, one hoe weeding at 12 WAP, one hoe weeding at $12 \mathrm{WAP}$, one hoe weeding at $20 \mathrm{WAP}$ and a monthly hoe weeding till 30 WAP.

\section{Field Establishment}

Prior to cultivation, the vegetation cover of the experimental sites was slashed to ground level, after which the land was disc ploughed, harrowed and ridged. The experimental site for each year had an area of $4212 \mathrm{~m}^{2}$. Each sub plot consisted of four rows of $5 \mathrm{~m}$ long. Ten threeeyed cane setts were laid horizontally end-to-end per row. NPK fertilizer was applied at $150 \mathrm{~kg} \mathrm{~N}$, $60 \mathrm{~kg} \mathrm{P}$ and $90 \mathrm{~kg} \mathrm{~K}$ in equal halves at planting and 8-10WAP.

\section{Data Collection}

Data on weed density and biomass were collected at 16, 20, 40WAP and 12, 16, 20,30, 40 WAP, respectively. Weed density was monitored in four randomly placed $\left(0.25 \mathrm{~m}^{2}\right)$ quadrats discreetly per sub plot on each assessment date. Weed seedlings in each quadrat were counted pulled out. Dry matter production by the weeds was determined from the harvested weeds within each quadrat during each sampling periods. Samples from the same plots were bulked and oven dried at $80^{\circ} \mathrm{c}$ to a constant weight. The crop data collected were sugarcane tiller count per plot at $12,16,20,30,40 \mathrm{WAP}$ and cane yield extrapolated to tones per hectare at harvest.

\section{Data Analysis}

Average weed density and weed biomass, tiller count at $40 \mathrm{WAP}$ and cane yield at harvest were subjected to analysis of variance (ANOVA) using Genstat Discovery Edition for each year of study. Where F-ratios were significant $(\mathrm{p}<0.05)$; means were separated using Fisher's protected least significant difference. The cane yield and tiller count data were correlated against the weed parameters. 


\section{Results}

\section{Weed Species Composition}

Thirty-five (35) weed species, made up of 18 annual and 17 perennial weed species within 30 genera were identified in all sites used for the study. Weed species indentified comprised of 20 broadleaves, 12 grasses and three (3) sedges. Twenty-seven weed species were encountered in 2009, 29 in 2010, 31 in 2011 and 30 in the ratoon crop site (Table 1). Ten weed species constituted more than $60 \%$ of total weed species in each site. Eight of these weed species: Panicum maximum, Rottboellia cochinchinensis, Cynodon dactylon, Eleusine indica, Imperata cylindrica, Panicum repens, Cyperus rotundus and Andropogon gayanus were enumerated in the four trial sites (Table 2) while the five most abundant weed species are grasses and are arranged in this sequence as follows: Rottboellia cochinchinensis (10.916 \%), Panicum maximum (9.399 \%), Imperata cylindrica (8.644\%), Panicum repens (7.747\%, and Cynodon dactylon (6.659\%).

\section{Weed infestation and dry matter production}

Mean weed density was significantly influenced by sugarcane variety and weeding regime except the ratoon crop in 2011 where sugarcane varieties had similar effect on mean weed population (Table 3). Var. Co 957 had significantly lower mean weed density in 2009 and 2011 and significantly higher in 2010 while var. B47419 had significantly lower in 2009 and 2011 which was similar to what was obtained in var. ILS 001 in 2009 and var. ILS 002 in 2011 plots.

Monthly hoe weeded plots had significantly lower mean weed density while the plots where no weed was removed had significantly higher mean weed density which was similar to other hoe weeded plots except plots hoe weeded at 20 WAP.

Interaction effect between sugarcane variety and weeding regime on mean weed density was observed in 2010 (Table 4). Sugarcane variety had similar mean weed density across the weeding regimes except under monthly hoe weeded where significantly lower mean weed population was observed across the sugarcane varieties.

Mean weed biomass was significantly influenced by sugarcane variety and weeding regime except in 2009 and ratoon crop in 2011 where weeding regime and sugarcane varieties had similar effect on mean weed weight, respectively (Table 5). Var. Co 957 had significantly lower mean weed dry weight except in 2011 while B47419 had relatively higher weed biomass in all the trial years were significant differences were observed. Other sugarcane varieties evaluated were similar in one point to another with either var. Co 957 or var. B47419.

Mean weed dry weight obtained under the weeding regime plots showed that, monthly hoe weeding plots had significantly lower mean weed biomass while weedy check had relatively higher weed weight. The later plots had similar weed weight to other hoe weeded plots in 2011 and the ratoon crop.

Interaction effects between sugarcane variety and weeding regime mean weed biomass were observed in 2009 and 2010 growing seasons (Table 6) and similar trend as observed mean weed population was observed across the sugarcane varieties.

\section{Effect of natural weed infestation on sugarcane tillering ability and cane yield}

Mean tiller count per plot of the sugarcane varieties for four assessment periods each year is presented in Table 7. The varieties evaluated had similar tillering ability. Although var. ILS 002 and var. ILS 001 had higher number of tillers in 2009 and 2011, respectively while B47419 and Var. Co 957 had more number of tillers in 2010 and in the ratoon crop, respectively.

In a similar manner, weeding regimes significantly influenced the production of tillers in sugarcane crop. Monthly hoe weeded plots had significantly mean tiller count follow while weedy check had significantly lower number of tillers. Other weeding regimes had similar mean tiller count across the years. The earliness weed removal encourages increase in sugarcane tiller production.

Interaction effects of sugarcane varieties with weeding regime were highly significant for cane yield (Table 8 ). The monthly hoe weeded plots had significantly higher cane yield. A relatively higher cane yield was obtained from plots planted to var. Co 957 (52 - $72 \mathrm{t} / \mathrm{ha})$ while the ratoon crop of the same var. above yielded $48 \mathrm{t} / \mathrm{ha}$. The ILS varieties followed var. Co 957 in cane yield. The cane yield obtained from other plots increases with earliness in weed removal. The 
percentage reduction in cane yield as compared to the yield obtained in monthly hoe weeded plots shows that, plots hoe weeded at 4 WAP suffered $80.51-90.52 \%$ lost in cane yield, 88.55 - 92.95 $\%$ loss in cane yield was obtained in plots hoe weeded at 8 WAP while $91.74-94.55 \%, 90.57$ $93.75 \%$ and $94.95-97.55 \%$ were cane yields lost recorded from plots hoe weeded at $12 \mathrm{WAP}$, 20 WAP and weedy check, respectively.

Coefficient of correlation of weed parameters and tiller count with the cane yield (Table 9) showed that weed density and weed biomass were negatively significant correlated while number of tillers positively correlated with cane yield. The correlations were more consistently significant between weed population and cane yield than between weed biomass and cane yield.

\section{Discussion}

Variety recommendations are based primarily on yield (tonnage and sugar), stubble longevity, disease/insect reaction, weed competition and herbicide tolerance. Sugarcane varieties can vary in growth characteristics which can directly affect weed competition. Sugarcane cultivars differ with regards to time of emergence following planting either in May as rainfed cultivation or November under irrigation; stalk population; canopy characteristics, such as leaf architecture; and ratooning ability (measured by survival and vigor of the crop following repeated annual harvests); all of which may affect the variety's competitiveness with weeds (Jones et al., 2006). The variability might be due to the variable genetic potential which showed different results in a particular set of environment and ecological conditions of the experimental crop.

In this study, Rottboellia cochinchinensis (Lour.)W.D.Clayton, Panicum maximum Jacq, Imperata cylindrica L., Panicum repens L., Cynodon dactylon L. and Cyperus rotundus L. were found to be the major weed problems of sugarcane in Ilorin. Webster (2000) reported that, annual grasses which include Rottboellia cochinchinensis (Lour.) W.D. Clayton, Brachiaria platyphylla (Griseb.) Nash, and Panicum fasciculatum Sw.; Sorghum halepense (L.) Pers. and Cynodon dactylon (L.) Pers.; Ipomoea spp.; and Cyperus spp were the major weed problems in sugarcane in the tropics while Ndarubu et al. (2006) reported grasses to be of highest density, followed by the broadleaved weeds, while the sedges had the least density in Nigeria.

In this study, the highest diversity of species was observed among the broadleaved weeds; followed by the grasses while the sedges had the least diversity. The occurrence of these weed species on the trial fields could be attributed to the long period of cultivation, monocropping with sugarcane and application of irrigation water from a natural source that might be contaminated with weeds. The observed high density of grasses and high species diversity may be due to high tillering ability of grasses and the wide edaphic adaptability of broadleaf weeds (Akobundu 1997). Broadleaf weeds are easier to control through cultural practices than grasses and sedges that possess adaptive features for vegetative propagation, which facilitate their regeneration in subsequent years without changes in species (Ekeleme et al., 2004).

There was a decrease in number of tillers with an increase in weed population which resulted in reduction in cane weight. Reduction in cane yield ranging from $80.51 \%$ to $97.55 \%$ was due to weed crop competition which prolonged from 4 to $20 \mathrm{WAP} /$ weedy check. These results are supported by Fadayomi and Abayomi, (1988), Kolo et al. (1999) in Nigeria who concluded that uncontrolled weed interference in the crop has been reported to cause between 12 and $78 \%$ reductions in cane yield depending on weed species, weed density and the sugarcane crop cycle. Chauhan and Srivastava (2002) in India reported 32.0 to $45.45 \%$ yield losses due to weedcrop competition. Similarly, Singh and Tomar (2003) in India reported 20.5 and $74.5 \%$ reduction in cane yield because of weed-crop competition. Muhammad et al. (2010) reported a decrease of 9.84 to $56.89 \%$ in stripped cane yield in Pakistan. In U.S.A. weed crop competition of 3, 6 and 9 WAP reduced yield of sugarcane, 77.6, 50.6 and $41.7 \%$ respectively (Zimdahl, 1980). Khan et al. (2004) reported that cane yield of sugarcane crop is affected more than 20-25\% due to weeds while Nayyar (1994) and Patel et al. (2007) concluded that zero weed-crop competition gave higher cane yield than different weed-crop competition periods.

Increase in weed population with an increase in weed-crop competition period could be due to 
more time availed for weed seeds to germinate, whereas increase in weed biomass with time was due to utilization of environmental resources by weeds for a longer period of time compared with monthly hoe weeded.

Coefficient of correlation of weed density and weed biomass with cane yield showed that the increase in these weed parameters will result in decrease in cane yield whereas tiller count was positively and highly significant, an increase in tillering ability resulted in simultaneously increase in cane yield. Ramdoyal (1999) in Mauritius and Abdul Fatah et al. (2006) Thatta, Pakistan reported similar results between number of tillers and cane yield.

\section{Conclusion}

The yield of sugarcane was linearly decreased with increasing weed-crop competition duration with maximum decrease in weedy plot. Weeds should be removed immediately after the emergence to get maximum cane yield. Growth parameters that are negatively and significantly correlated with weed parameters should be used for selection of weed tolerance sugarcane variety(s) for commercial sugar production.

\section{References}

Abdul Fatah, S., Junijo, S., Ahmed, A. and Aslam, M. (2006). Evaluation of different promising sugarcane varieties for some quantitative and qualitative attribute under Thatta (Pakistan) conditions. International Journal of Agriculture and Biology 8(2): 195-197.

Chauhan, R.S. and Srivastava, T.K. (2002). Influence of planting technique on growth and yield ofsugarcane. Indian Journal of Weed Science 34(3-4): 318-319.

Ekeleme, F., Chikoye, D. and Akobundu, I.O. 2004. Changes in size and composition of weed communities during planted and natural fallow. Basic and Applied Ecology 5:25-33.

Fadayomi O. and Abayomi, Y.A. (1988). Effects of varying periods of weed interference on Sugarcane (Saccharum officinarum L), growth and yield. Nigerian Journal of Weed Science. 1: 65 - 70.

Jones, C. A., Griffin, J. L., Etheredge, L. M. and Judice, W. E. 2006. Response of red morningglory (Ipomoea coccinea L.) to shade and soil applied herbicides. Proceedings of South Weed Science Society. 59:3.

Khan, B., Jama, M. and Azim, H. (2004). Effect of weeds on cane yield and content odf sugarcane. Pakistan Journal of Weed Science Research 10(1-2):47-50.

Kolo, I.N., Adesiyu, A.A., Misari, S. M., Busari, L.D. and Ndarubu, A. A. (1999). Weed as alternative host of chewing sugarcane stem borers. Nigerian Journal of Plant Protection 18: 56-66.

Nayyar, M.M., Shafi, M., Shah, M.L. and Mahmood, T. (1994). Critical period of weed control in sugarcane. In: Abstract of $4^{\text {th }}$ all Pakistan Weed Science Conference, University of Agriculture, Faisalabad, Pakistan, March 26-27.

Ndarubu, A.A., Fadayomi, O. and Oyejola, B.A. (2006). Use of the additive main effect and multiplicative interaction (AMMI) and average linkage cluster analysis for the mapping of weed occurrence on the sugarcane estate of the Nigerian Sugar Company (NISUCO), Bacita, Nigeria. Nigerian Journal of Weed Science 19:7-21.

Patel, C.L., Patel, D.D. and Patel, M.N. (2007). Critical period of crop weed competition in sugarcane (var Co LK 8001). Indian Sugar 56(12): 27-32.

Phogat, B.S., Bhan, V.M. and Dhawa, R.S. (1990). Studies on the competing ability of sugarcane with weeds. Indian Journal of Weed Science 27:37-41.

Punzelan, F.L. and Cruzz, D. L. (1981). Effect of duration of weed competition and weed control in sugarcane. Philippine Journal of Weed Science 8:15-18.

Ramdoyal, K. (1999). Genetic correlation and repeatability for agronomic characters in sugarcane population in contrasting environment and different crop year. Sugarcane International 4:6-12.

Singh, G., Pant, P.C. and Bhan, V.M. (1980). Studies on the critical period of weed control in in spring planted sugarcane. Indian Journal of Weed Science 12(2): 120124.

Singh, D. and Tomar, P. K. (2003). Studies on critical period of crop weed competition in 
late planted sugarcane. Indian Sugar, 53(8): 579-583.

Srivastava, T.K., Singh, A.K. and Srivastava, S.N. (2003). Critical period of weed competition in sugarcane ratoon. Indian Journal of Weed Science 34(3-4): 320-321.

USRI (2009). Unilorin Sugar Research Institute: Report of Research activities (2005-2009). Pg 34-38.

Table 1 Mean relative abundance $(\%)$ of weed species encountered in sugarcane fields

\begin{tabular}{|c|c|c|c|c|c|c|}
\hline Weed Species & $\mathrm{LC}$ & MG & PC 2009 & PC 2010 & PC 2011 & Ratoon 2011 \\
\hline Trianthema portulacastrum $\mathrm{L}$. & $\mathrm{A}$ & $\mathrm{B}$ & 0.891 & 0.510 & 0.153 & 0.554 \\
\hline Achyranthes aspera $\mathrm{L}$. & A & B & - & - & 0.382 & - \\
\hline Celosia leptostachya Benth. & A & B & 2.836 & 1.8718 & 1.147 & 2.215 \\
\hline Ageratum conyzoides $\mathrm{L}$ & A & $\mathrm{B}$ & 1.378 & 2.041 & 1.651 & - \\
\hline Aspilia africana pers C.D Adams & $\mathrm{P}$ & $\mathrm{B}$ & 1.702 & 1.8718 & 0.917 & 1.177 \\
\hline Chromolaena odorata L. (RM) king & $\mathrm{P}$ & $\mathrm{B}$ & 2.998 & 2.211 & 0.765 & 1.107 \\
\hline Tridax procumbens $\mathrm{L}$. & A & B & 1.702 & 1.786 & 1.606 & 1.038 \\
\hline Cleome viscosa $\mathrm{L}$ & A & B & 2.431 & 2.466 & - & 1.523 \\
\hline Commelina diffusa Burn. & $\mathrm{P}$ & S & - & - & 1.682 & - \\
\hline Cyperus esculentus L. & $\mathrm{P}$ & $\mathrm{S}$ & 4.863 & 4.931 & 2.982 & 2.629 \\
\hline Cyperus rotundus $\mathrm{L}$. & $\mathrm{P}$ & $\mathrm{S}$ & 4.943 & 6.037 & 3.058 & 4.498 \\
\hline Mariscus alternifolius Vahl & $\mathrm{P}$ & $\mathrm{S}$ & 2.512 & 2.721 & 3.669 & 2.7682 \\
\hline Croton lobatus $\mathrm{L}$. & A & B & - & - & 0.994 & 1.107 \\
\hline Euphorbia heterophylla $\mathrm{L}$. & A & B & 1.054 & 1.020 & 2.141 & 1.524 \\
\hline Phyllanthus amarus Schum \& Thonn & $\mathrm{A}$ & $\mathrm{S}$ & 2.998 & 1.871 & 2.446 & - \\
\hline Desmodium salicifolium (Poir) DC & A & B & 1.216 & - & 1.529 & - \\
\hline Tephrosia bracheolata Guill & A & $\mathrm{S}$ & 2.836 & 2.551 & 1.376 & 1.384 \\
\hline Sida acuta Burm. & $\mathrm{P}$ & B & 1.539 & 1.701 & - & 1.107 \\
\hline Sida rhombifolia $\mathrm{L}$. & $\mathrm{P}$ & B & 0.729 & - & 1.452 & 1.384 \\
\hline Boerhavia coccinea Mill & $\mathrm{P}$ & $\mathrm{B}$ & - & - & - & 0.692 \\
\hline Boerhavia diffusa $\mathrm{L}$. & $\mathrm{P}$ & $\mathrm{B}$ & 2.188 & 2.126 & 0.841 & 2.007 \\
\hline Andropogon gayanus Kunth & $\mathrm{P}$ & G & 4.619 & 6.463 & 6.269 & 8.374 \\
\hline Axonopus compresus Sw. P. Beauv & $\mathrm{P}$ & $\mathrm{G}$ & 5.835 & 2.806 & 0.917 & 1.176 \\
\hline Bracharia lata (Schumach) C.E & A & $\mathrm{G}$ & 1.458 & 1.361 & 1.147 & 1.868 \\
\hline Cynodon dactylon $\mathrm{L}$. & $\mathrm{P}$ & G & 7.050 & 5.528 & 8.104 & 5.952 \\
\hline Eleusine indica Gaertn & A & G & 7.050 & 4.762 & 8.180 & 3.806 \\
\hline Imperata cylindrica $\mathrm{L}$. & $\mathrm{P}$ & $\mathrm{G}$ & 4.943 & 12.245 & 10.092 & 6.575 \\
\hline Panicum maximum Jacq & $\mathrm{P}$ & $\mathrm{G}$ & 13.047 & 10.034 & 8.563 & 5.952 \\
\hline Panicum repens L. & $\mathrm{P}$ & $\mathrm{G}$ & 6.321 & 5.017 & 10.168 & 9.481 \\
\hline Paspalum scrobiculatum L. & $\mathrm{P}$ & $\mathrm{G}$ & - & 2.721 & - & 3.253 \\
\hline Pennisetum polystachion $\mathrm{L}$ & A & $\mathrm{G}$ & & 0.255 & 0.535 & 6.298 \\
\hline Pennisetum violaceum Lam. & A & $\mathrm{G}$ & & 0.425 & 0.382 & 7.889 \\
\hline Rottboellia cochinchinensis (Lour) & A & G & 8.833 & 10.119 & 15.367 & 9.343 \\
\hline Mitracarpus villosus Sw. DC. & A & $\mathrm{B}$ & 2.026 & 1.871 & 1.376 & 1.107 \\
\hline Physalis angulata $\mathrm{L}$ & A & $\mathrm{B}$ & 0 & 0.680 & 0.153 & 2.215 \\
\hline
\end{tabular}

$\mathrm{LC}=$ life cycle, $\mathrm{MG}=$ morphological group, $\mathrm{A}=$ annual weed species, $\mathrm{P}=$ perennial weed species, $\mathrm{B}=$ broadleaf, $\mathrm{G}=\mathrm{grass}, \mathrm{S}=$ sedge, $\mathrm{PC}=$ plant crop.
Webster, T. M. (2000). Weed survey - southern states. Proceedings of South Weed Science

Zimdahl, R.L. (1980). Weed crop competition: A review- International Plant Protection Centre, Oregon State University, USA: 6869. Society.53:247-274. 
Table 2: Ten worst weed species identified in different sugarcane cultivation sites

\begin{tabular}{|c|c|c|c|c|c|c|c|}
\hline \multirow[b]{3}{*}{ Weed Species } & \multicolumn{6}{|c|}{ Relative Abundance (\%) } & \multirow{3}{*}{$\begin{array}{l}\text { Mean Rel. } \\
\text { Abundance } \\
(\%)\end{array}$} \\
\hline & \multicolumn{5}{|c|}{ Plant Crop } & \multirow{2}{*}{$\begin{array}{l}\text { Ratoon Crop } \\
2011\end{array}$} & \\
\hline & MG & LC & 2009 & 2010 & 2011 & & \\
\hline Panicum maximum Jacq & G & $\mathrm{P}$ & 13.047 & 10.034 & 8.563 & 5.952 & 9.399 \\
\hline Rottboellia cochinchinensis (Lour) & G & A & 8.833 & 10.119 & 15.367 & 9.343 & 10.916 \\
\hline Cynodon dactylon $\mathrm{L}$ & G & $\mathrm{P}$ & 7.050 & 5.528 & 8.104 & 5.952 & 6.659 \\
\hline Eleusine indica Gaertru & G & A & 7.050 & 4.762 & 8.180 & 3.806 & 5.949 \\
\hline Imperata cylindrica $\mathrm{L}$ & G & $\mathrm{P}$ & 4.943 & 12.245 & 10.092 & 6.575 & 8.644 \\
\hline Panicum repens $\mathrm{L}$ & G & $\mathrm{P}$ & 6.321 & 5.017 & 10.168 & 9.481 & 7.747 \\
\hline Cyperus esculentus $\mathrm{L}$ & $\mathrm{s}$ & $\mathrm{P}$ & 4.863 & 4.931 & 2.982 & - & 3.194 \\
\hline Cyperus rotundus $\mathrm{L}$ & $\mathrm{S}$ & $\mathrm{P}$ & 4.943 & 6.037 & 3.058 & 4.498 & 4.634 \\
\hline Mariscus alternifolius Vahl & $\mathrm{S}$ & $\mathrm{P}$ & - & 2.721 & 3.669 & - & 1.598 \\
\hline Andropogon gayanus Kunth & G & $\mathrm{P}$ & 4.619 & 6.463 & 6.269 & 8.374 & 6.431 \\
\hline Chromolaena odorata L. (RM) king & B & $\mathrm{P}$ & 2.998 & - & - & - & 0.749 \\
\hline Pennisetum polystachion $\mathrm{L}$ & G & A & - & - & - & 6.298 & 1.575 \\
\hline Pennisetum violaceum Lam & $\mathrm{G}$ & A & & & & 7.889 & 1.972 \\
\hline
\end{tabular}

$\mathrm{LC}=$ life cycle, $\mathrm{MG}=$ morphological group, $\mathrm{A}=$ annual weed species, $\mathrm{P}=$ perennial weed species, $\mathrm{B}=$ broadleaf, $\mathrm{G}=$ grass, $\mathrm{S}=$ sedge

Table 3: Influence of sugarcane variety and weeding regime on mean weed density $\left(\mathrm{no} / \mathrm{m}^{2}\right)$

\begin{tabular}{|c|c|c|c|c|}
\hline Treatment & Plant crop, 2009 & Plant crop, 2010 & Ratoon crop, 2011 & Plant crop, 2011 \\
\hline \multicolumn{5}{|l|}{ Variety } \\
\hline B47419 & $129 \mathrm{c}$ & $23 \mathrm{a}$ & 243 & $84 c$ \\
\hline Co 62175 & $111 \mathrm{ab}$ & $26 \mathrm{a}$ & 236 & $76 \mathrm{~b}$ \\
\hline Co 957 & $107 \mathrm{a}$ & $41 \mathrm{~b}$ & 209 & $70 \mathrm{a}$ \\
\hline ILS-001 & $105 \mathrm{a}$ & $27 \mathrm{a}$ & 236 & $82 c$ \\
\hline ILS-002 & $121 b c$ & $26 \mathrm{a}$ & 251 & $73 \mathrm{ab}$ \\
\hline Sed & 6.45 & 2.38 & 22.76 & 2.77 \\
\hline \multicolumn{5}{|l|}{ Weeding Regime } \\
\hline NHW & $149 \mathrm{c}$ & $52 \mathrm{c}$ & $300 c$ & $88 \mathrm{c}$ \\
\hline MHW & $25 \mathrm{a}$ & $13 \mathrm{a}$ & $45 a$ & $46 a$ \\
\hline HW4 & $138 \mathrm{c}$ & $21 \mathrm{~b}$ & $307 \mathrm{c}$ & $87 b c$ \\
\hline HW8 & $141 \mathrm{c}$ & $28 \mathrm{~b}$ & $300 \mathrm{c}$ & $80 \mathrm{bc}$ \\
\hline HW12 & $135 \mathrm{c}$ & $25 \mathrm{~b}$ & $214 b$ & $85 b c$ \\
\hline HW20 & $98 b$ & $31 b$ & $244 b$ & $174 b$ \\
\hline Sed & 10.25 & 3.44 & 31.24 & 6.83 \\
\hline \multicolumn{5}{|l|}{ ANOVA } \\
\hline Replication & 366.9 & 138.3 & 45848 & 1802.1 \\
\hline Variety & $1799.8^{*}$ & $900.4 * *$ & 4637 & $656.1 *$ \\
\hline Residual & 982.7 & 50.9 & 4661 & 204.4 \\
\hline Weeding Regime & $33540.0^{* *}$ & $2657.3 * *$ & $150923 * *$ & $3766.9 * *$ \\
\hline Interaction & 894.0 & $1078.3 * *$ & 6802 & 529.9 \\
\hline Residual & 788.3 & 88.9 & 7320 & 350.2 \\
\hline
\end{tabular}

NHW =no hoe weeding, MHW= monthly hoe weeding, HW4= hoe weeding at $4 \mathrm{WAP}, \mathrm{HW} 8=$ hoe weeding at 8 WAP, HW12= hoe weeding at $12 \mathrm{WAP}$, HW20= hoe weeding at $20 \mathrm{WAP}$ 
Table 4: Interaction between sugarcane varieties with weeding regime on mean weed density at 2010

\begin{tabular}{rrrrrrr}
\hline \multicolumn{7}{c}{ Weeding Regime } \\
\multicolumn{10}{c}{ Variety } & HW12 & HW20 & HW4 & HW8 & MHW & NHW \\
\hline B47419 & 31.44 & 22.78 & 16.44 & 27.00 & 9.89 & 30.33 \\
Co61275 & 31.89 & 27.89 & 28.11 & 25.67 & 14.44 & 23.67 \\
Co957 & 35.22 & 19.89 & 18.67 & 25.33 & 13.22 & 132.11 \\
ILS 001 & 32.33 & 25.44 & 19.33 & 32.78 & 15.22 & 34.67 \\
ILS 002 & 22.78 & 30.11 & 20.11 & 28.67 & 13.22 & 41.33 \\
& Sed & 7.423 & & 7.702 & & \\
\hline
\end{tabular}

NHW =no hoe weeding, MHW= monthly hoe weeding, HW4= hoe weeding at $4 \mathrm{WAP}, \mathrm{HW} 8=$ hoe weeding at $8 \mathrm{WAP}$, HW12= hoe weeding at $12 \mathrm{WAP}, \mathrm{HW} 20=$ hoe weeding at $20 \mathrm{WAP}$

Table 5: Influence of sugarcane variety and weeding regime on mean weed biomass $\left(\mathrm{kg} / \mathrm{m}^{2}\right)$

\begin{tabular}{lllll}
\hline Treatment & Plant crop, 2009 & Plant crop, 2010 & Ratoon crop, 2011 & Plant crop, 2011 \\
\hline Variety & & & \\
B47419 & $0.401 \mathrm{c}$ & $1.128 \mathrm{a}$ & $1.186 \mathrm{~d}$ & 0.784 \\
Co 62175 & $0.316 \mathrm{ab}$ & $0.783 \mathrm{~b}$ & $0.850 \mathrm{a}$ & 0.830 \\
Co 957 & $0.289 \mathrm{a}$ & $0.193 \mathrm{a}$ & $0.952 \mathrm{c}$ & 0.744 \\
ILS-001 & $0.370 \mathrm{bc}$ & $0.497 \mathrm{~b}$ & $0.896 \mathrm{~b}$ & 0.911 \\
ILS-002 & $0.389 \mathrm{bc}$ & $0.522 \mathrm{~b}$ & $0.902 \mathrm{~b}$ & 0.877 \\
Sed & 0.039 & 0.081 & 0.112 & 0.126 \\
Weeding Regime & & & & \\
NHW & 0.387 & $0.762 \mathrm{~d}$ & $1.198 \mathrm{~b}$ & $1.061 \mathrm{~b}$ \\
MHW & 0.325 & $0.391 \mathrm{a}$ & $0.592 \mathrm{a}$ & $0.074 \mathrm{a}$ \\
HW4 & 0.384 & $0.678 \mathrm{~b}$ & $1.091 \mathrm{~b}$ & $0.879 \mathrm{~b}$ \\
HW8 & 0.342 & $0.665 \mathrm{a}$ & $1.063 \mathrm{~b}$ & 1.052 \\
HW12 & 0.331 & $0.703 \mathrm{~b}$ & $0.788 \mathrm{ab}$ & $0.989 \mathrm{~b}$ \\
HW20 & 0.349 & 0.073 & $1.012 \mathrm{~b}$ & $0.921 \mathrm{~b}$ \\
Sed & 0.036 & & 0.117 & 0.131 \\
ANOVA & & & \\
Replication & 0.154 & 0.134 & 0.008 & 2.245 \\
Variety & $0.042^{*}$ & $0.215^{* *}$ & $0.319 *$ & 0.082 \\
Residual & 0.014 & 0.059 & 0.094 & 0.144 \\
Weeding Regime & 0.011 & $0.270^{* *}$ & $0.757^{*}$ & $2.129 * *$ \\
Interaction & $0.025^{*}$ & $0.141^{* *}$ & 0.139 & 0.135 \\
Residual & 0.009 & 0.039 & 0.103 & 0.129 \\
\hline NW & & &
\end{tabular}

NHW =no hoe weeding, MHW= monthly hoe weeding, HW4= hoe weeding at $4 \mathrm{WAP}, \mathrm{HW} 8=$ hoe weeding at $8 \mathrm{WAP}$, HW12= hoe weeding at $12 \mathrm{WAP}, \mathrm{HW} 20=$ hoe weeding at $20 \mathrm{WAP}$ 
Table 6 Interaction between sugarcane variety with weeding regime on mean weed biomass in 2009 and 2010

Weeding Regime at 2009

$\begin{array}{lclllll}\text { VARIETY } & \text { HW12 } & \text { HW20 } & \text { HW4 } & \text { HW8 } & \text { MHW } & \text { NHW } \\ \text { B47419 } & 0.390 & 0.364 & 0.353 & 0.390 & 0.501 & 0.407 \\ \text { Co61275 } & 0.330 & 0.283 & 0.376 & 0.376 & 0.194 & 0.337 \\ \text { Co957 } & 0.288 & 0.354 & 0.359 & 0.306 & 0.077 & 0.349 \\ \text { ILS 001 } & 0.316 & 0.428 & 0.418 & 0.349 & 0.261 & 0.449 \\ \text { ILS 002 } & 0.329 & 0.317 & 0.417 & 0.288 & 0.593 & 0.392 \\ & \text { Sed } & 0.0831 & 0.0803 & & & \end{array}$

Weeding Regime at 2009

$\begin{array}{lcccccc}\text { B47419 } & 0.051 & 0.109 & 0.188 & 0.162 & 0.400 & 0.246 \\ \text { Co61275 } & 0.648 & 0.898 & 0.846 & 0.772 & 0.558 & 0.976 \\ \text { Co957 } & 0.973 & 1.495 & 1.148 & 1.277 & 0.353 & 1.524 \\ \text { ILS 001 } & 0.405 & 0.468 & 0.740 & 0.430 & 0.471 & 0.470 \\ \text { ILS 002 } & 0.667 & 0.547 & 0.467 & 0.686 & 0.171 & 0.594 \\ & \text { Sed } & 0.1686 & 0.1621 & & & \end{array}$

$\mathrm{NHW}=$ no hoe weeding, MHW= monthly hoe weeding, HW4= hoe weeding at $4 \mathrm{WAP}, \mathrm{HW} 8=$ hoe weeding at 8 WAP, HW12= hoe weeding at $12 \mathrm{WAP}, \mathrm{HW} 20=$ hoe weeding at $20 \mathrm{WAP}$

Table 7: Effect of weeds infestation on sugarcane tillering ability (tillers/plot)

\begin{tabular}{lllll}
\hline Treatment & Plant crop, 2009 & Plant crop, 2010 & Ratoon crop, 2011 & Plant crop, 2011 \\
\hline Variety & & & & \\
B47419 & 139 & 61 & 101 & 57 \\
Co 62175 & 112 & 56 & 78 & 58 \\
Co 957 & 148 & 59 & 118 & 51 \\
ILS-001 & 131 & 56 & 90 & 85 \\
ILS-002 & 178 & 46 & 91 & 62 \\
Sed & 25.52 & 6.61 & 24.28 & 12.36 \\
Weeding Regime & & $37 \mathrm{~d}$ & $68 \mathrm{~b}$ & $17 \mathrm{c}$ \\
NHW & $56 \mathrm{~d}$ & $93 \mathrm{a}$ & $169 \mathrm{a}$ & $145 \mathrm{a}$ \\
MHW & $259 \mathrm{a}$ & $60 \mathrm{~b}$ & $101 \mathrm{~b}$ & $61 \mathrm{~b}$ \\
HW4 & $202 \mathrm{~b}$ & $48 \mathrm{c}$ & $84 \mathrm{~b}$ & $52 \mathrm{~b}$ \\
HW8 & $135 \mathrm{c}$ & $48 \mathrm{c}$ & $72 \mathrm{~b}$ & $52 \mathrm{~b}$ \\
HW12 & $142 \mathrm{c}$ & $49 \mathrm{c}$ & $80 \mathrm{~b}$ & $49 \mathrm{~b}$ \\
HW20 & $56 \mathrm{~d}$ & 4.79 & 24.20 & 11.73 \\
Sed & 22.14 & & & \\
ANOVA & & 204 & 11179 & 6489 \\
Replication & 135902 & 597 & 3454 & 2987 \\
Variety & 10428 & 393 & 4074 & 1375 \\
Residual & 5862 & $5661^{*}$ & $21239^{*}$ & $27937^{*}$ \\
Weeding Regime & $96611^{* *}$ & 511 & 5048 & 1460 \\
Interaction & 2193 & 185 & 4392 & 1032 \\
Residual & 3677 & & & \\
\hline NW & & & & \\
\hline
\end{tabular}

NHW $=$ no hoe weeding, MHW= monthly hoe weeding, HW4= hoe weeding at $4 \mathrm{WAP}, \mathrm{HW} 8=$ hoe weeding at 8 WAP, HW12= hoe weeding at $12 \mathrm{WAP}, \mathrm{HW} 20=$ hoe weeding at $20 \mathrm{WAP}$ 
Table 8: Interaction between sugarcane variety with weeding regime on mean cane yield $(\mathrm{t} / \mathrm{ha})$

\begin{tabular}{|c|c|c|c|c|c|c|c|}
\hline \multirow[b]{2}{*}{ VARIETY } & \multicolumn{7}{|c|}{ Weeding Regime } \\
\hline & \multicolumn{6}{|c|}{ Plant Crop of 2009} & \multirow[b]{2}{*}{0.42} \\
\hline $\begin{array}{l}\text { B47419 } \\
\text { Co61275 } \\
\text { Co957 } \\
\text { ILS 001 } \\
\text { ILS } 002\end{array}$ & $\begin{array}{l}0.92 \\
0.99 \\
1.83 \\
\text { Sed }\end{array}$ & $\begin{array}{l}0.49 \\
0.53 \\
0.42 \\
0.61 \\
0.67\end{array}$ & $\begin{array}{l}1.11 \\
0.82 \\
1.36 \\
0.34 \\
0.90\end{array}$ & $\begin{array}{l}2.69 \\
1.74 \\
3.03 \\
0.97 \\
3.90\end{array}$ & $\begin{array}{l}39.98 \\
1.78 \\
60.32 \\
41.50 \\
36.61\end{array}$ & $\begin{array}{l}0.24 \\
34.93 \\
0.25 \\
0.00 \\
0.67 \\
3.59\end{array}$ & \\
\hline ILS 002 & \multicolumn{7}{|c|}{ Plant Crop of 2010} \\
\hline $\begin{array}{l}\text { B47419 } \\
\text { Co61275 } \\
\text { Co957 } \\
\text { ILS } 001 \\
\text { ILS } 002\end{array}$ & $\begin{array}{l}0.54 \\
0.93 \\
0.88 \\
0.75\end{array}$ & $\begin{array}{l}0.60 \\
0.56 \\
0.13 \\
0.53 \\
0.46\end{array}$ & $\begin{array}{l}0.98 \\
0.92 \\
0.82 \\
1.71 \\
1.62\end{array}$ & $\begin{array}{l}1.36 \\
0.88 \\
2.22 \\
1.81 \\
1.64\end{array}$ & $\begin{array}{l}34.62 \\
0.66 \\
72.54 \\
50.70 \\
55.14\end{array}$ & $\begin{array}{l}0.49 \\
48.81 \\
0.18 \\
0.78 \\
0.51\end{array}$ & 0.20 \\
\hline Sed & \multicolumn{7}{|c|}{ Plant Crop of 2011} \\
\hline $\begin{array}{l}\text { B47419 } \\
\text { Co61275 } \\
\text { Co957 } \\
\text { ILS } 001 \\
\text { ILS } 002\end{array}$ & $\begin{array}{l}1.03 \\
1.21 \\
1.93 \\
1.99 \\
\text { Sed }\end{array}$ & $\begin{array}{l}0.88 \\
1.00 \\
0.98 \\
1.15 \\
0.06\end{array}$ & $\begin{array}{l}1.85 \\
0.56 \\
1.23 \\
1.39 \\
1.37\end{array}$ & $\begin{array}{l}4.74 \\
2.94 \\
6.07 \\
2.15 \\
2.17\end{array}$ & $\begin{array}{l}32.85 \\
5.96 \\
63.07 \\
34.07 \\
42.72\end{array}$ & $\begin{array}{l}2.27 \\
22.61 \\
0.15 \\
0.99 \\
0.72 \\
7.79\end{array}$ & 0.07 \\
\hline \multicolumn{8}{|c|}{ Ratoon Crop of 2011} \\
\hline B47419 & 1.07 & 1.51 & 3.54 & 3.05 & 34.37 & 0.19 & \\
\hline Co61275 & & 0.48 & 1.79 & 4.16 & 7.09 & 26.37 & 0.31 \\
\hline Co957 & 1.07 & 1.96 & 2.90 & 2.63 & 48.12 & 0.68 & \\
\hline ILS 001 & 1.14 & 1.34 & 1.52 & 3.28 & 47.19 & 0.29 & \\
\hline ILS 002 & $\begin{array}{l}0.82 \\
\text { Sed }\end{array}$ & 1.01 & 1.43 & 2.09 & 36.45 & $\begin{array}{c}0.29 \\
4.24\end{array}$ & \\
\hline
\end{tabular}

NHW $=$ no hoe weeding, MHW= monthly hoe weeding, HW4= hoe weeding at $4 \mathrm{WAP}, \mathrm{HW} 8=$ hoe weeding at 8 WAP, HW12= hoe weeding at $12 \mathrm{WAP}, \mathrm{HW} 20=$ hoe weeding at $20 \mathrm{WAP}$

Table 9: Coefficient of correlation for weed parameters and tiller count with cane yield

\begin{tabular}{|c|c|c|c|c|}
\hline & Dependent varial & ane Yield t/ha) & & \\
\hline Independent variables & 2009 cane yield & 2010 cane yield & 2011 Ration cane yield & 2011 Cana yield \\
\hline Weed density @16 WAP & $-0.1456 \mathrm{~ns}(7.89)$ & $-0.2827 *(5.20)$ & $-0.3852 *(11.8)$ & $-0.2876 * *(10.0)$ \\
\hline Weed density@20 WAP & $-0.6235 * *(6.23)$ & $-0.3165 *(5.14)$ & $-0.4272 \mathrm{~ns}(12.3)$ & $-0.0147 * *(9.83)$ \\
\hline Weed density@40 WAP & $-0.6337 * *(6.17)$ & $-0.2143 *(5.29)$ & $-0.5015 * *(11.4)$ & $-0.3793 * *(9.40)$ \\
\hline Weed biomass@12 WAP & $0.5463 * *(6.68)$ & $0.5014 * *(4.69)$ & $-0.2886 *(11.9)$ & $-0.2512 *(10.4)$ \\
\hline Weed biomass@16 WAP & $-0.0768 \mathrm{~ns}(7.95)$ & $-0.1897 n s(5.32)$ & $-0.3266 n s(12.3)$ & $-0.0416 \mathrm{~ns}(10.3)$ \\
\hline Weed biomass@20 WAP & $0.2701 *(7.67)$ & $-0.1258 \mathrm{~ns}(5.38)$ & $-0.5587 \mathrm{~ns}(12.2)$ & $-0.1485 * *(10.1)$ \\
\hline Weed biomass@30 WAP & $-0.1971 *(7.81)$ & $-0.2815 *(5.20)$ & $-0.4487 * *(10.7)$ & $-0.4960 * *(9.71)$ \\
\hline Weed biomass@40 WAP & $-0.4930 * *(6.93)$ & $-0.3113 *(5.15)$ & $-0.4732 \mathrm{~ns}(12.2)$ & $-0.1517 * *(9.58)$ \\
\hline Tiller count @12 WAP & $0.4502 * *(7.12)$ & $0.6884 * *(3.93)$ & $0.5147 *(11.9)$ & $0.2504 * *(9.32)$ \\
\hline Tiller count@16 WAP & - & $0.6786^{* *}(3.98)$ & $0.5221 * *(11.3)$ & $0.3876^{* *}(9.27)$ \\
\hline Tiller count @30 WAP & - & $0.6884 * *(3.93)$ & $0.6218 * *(11.5)$ & $0.3569 * *(8.51)$ \\
\hline Tiller count @40 WAP & $0.5738 * *(6.53)$ & $0.7200 * *(3.76)$ & $0.6252 * *(8.06)$ & $0.7552 * *(8.48)$ \\
\hline
\end{tabular}

*significant at $0.05, * *$ significant at $0.01, \mathrm{~ns}=$ non-significant, standard error in parenthesis, - missing data 